
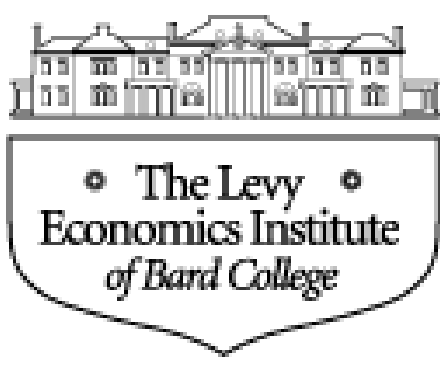

Working Paper No. 450

\title{
Extending Minsky's Classifications of Fragility to Government and the Open Economy
}

By

\section{Randall Wray}

The Levy Economics Institute Working Paper Collection presents research in progress by

Levy Institute scholars and conference participants. The purpose of the series is to disseminate ideas to and elicit comments from academics and professionals.

The Levy Economics Institute of Bard College, founded in 1986, is a nonprofit, nonpartisan, independently funded research organization devoted to public service. Through scholarship and economic research it generates viable, effective public policy responses to important economic problems that profoundly affect the quality of life in the United States and abroad.

The Levy Economics Institute

$$
\text { P.O. Box } 5000
$$

Annandale-on-Hudson, NY 12504-5000

http://www.levy.org

Copyright (C) The Levy Economics Institute 2006 All rights reserved. 


\begin{abstract}
Minsky's classification of fragility according to hedge, speculative, and Ponzi positions is well-known. He wrote about fragile positions of individual firms and of the economy as a whole, with the economy transitioning naturally from a robust financial structure (dominated by hedge units) to a fragile structure (dominated by speculative units). In most of Minsky's writing, he introduced government through its impact on the private sector with its spending and balance sheet operations as stabilizing forces (although he insisted that stability is ultimately destabilizing). On a few occasions he also analyzed the government's own balance sheet position. More rarely, Minsky extended his analysis to the open economy, examining the fragility of external debt positions. In these works, he analyzed the United States as the "world's bank" and discussed the impact of various U.S. balance sheet positions on the rest of the world. This paper will carefully examine Minsky’s position on these topics, and will offer an extension of Minsky’s work. It will also examine the "sustainability" of the current "twin U.S. deficits."

JEL Classifications: E32, E42, E62, F4, G15
\end{abstract}

Keywords: Hyman Minsky, financial fragility, financial instability hypothesis, current account deficit, budget deficit 
Minsky’s best-known contribution is his tripartite classification of balance sheets: hedge, speculative, and Ponzi. A hedge position is one in which the cash flows arising from the liability structure can be fully met out of the prospective income flows from assets; both interest and principal payments can be met as they come due. A speculative position is one which can meet interest payments, but principal will have to be rolled-over until some date in the future, at which time income flows are expected to rise. Finally, a Ponzi unit cannot even make interest payments out of current and near-term income flows, so they are capitalized as outstanding debt grows. A Ponzi position can be fraudulent (there is no likely scenario in which all commitments can be fulfilled-as in a pyramid scheme), but more likely results from unanticipated events (rates on floating interest liabilities rise, or expected cash flows are not forthcoming-either situation can push a speculative unit to Ponzi). This classification scheme plays a major role in Minsky’s theory of the endogenous transformation of the financial structure of the economy to fragility, subject to rising risk of financial crises.

Most of Minsky's analysis in this area focuses on the evolution of the domestic private sector of the economy, and most specifically on the rising fragility of the forprofit business sector. The government is introduced as a stabilizing sector, whose budget position moves counter cyclically toward deficits to prop up income-and most importantly, business profits_-in a downturn. Further, Minsky has analyzed the related private portfolio effects of “Big Government” budget movements. A budget deficit means that private sector portfolios will accumulate safe assets in a downturn. He is also justly famous for his analysis of the operation of the "Big Bank" (central bank) that intervenes as a lender of last resort, helping to put a floor on asset prices. In addition, he proposed various packages of policies that could be adopted, both by the central bank and by fiscal authorities, to help stabilize the private sector of the economy.

All of this is well-known. What is less appreciated is Minsky's treatment of possible fragility of the government sector, itself, and of national fragility. In fact, Minsky had long been concerned with the dollar's fortunes and implications for the U.S. of the break-down of Bretton Woods. He became increasingly worried about the debt 
positions of developing nations during the experiment with Reaganomics. The impacts of Supply Side economics on the U.S. federal budget were also of great concern to him. There have been some attempts by Minsky and by others after him to extend his classification of the private sector financial structure to governments and economies as a whole. This paper will explore the extent to which such an extension can be carried. Obviously, this exploration is not of mere academic interest, with the U.S. simultaneously running record (for it) balance of payments deficits and fairly large and rising budget deficits.

\section{MINSKY'S VIEWS ON THE FISCAL BALANCE}

Minsky realized early on that there is no default risk on national government debt issued in the sovereign's currency, nor any necessary problem with running "chronic" fiscal deficits. (Adelman and Minsky [1960?]); this is not surprising given that he was a close colleague of Abba Lerner) Further, he also recognized that only national government debt represents net financial wealth to the private sector (in a closed economy), and that a higher percent of national government debt in private portfolios makes private balance sheets safer. This, he argued, would normally stimulate private spending. Finally, even as early as 1960 he rigorously demonstrated that in a growing economy with a constant capital-output ratio and in which the private sector desires to hold some safe, liquid assets, a budget deficit is required to maintain full employment. (Adelman and Minsky $1960 *$ ) Indeed, he demonstrated that the national debt must grow at the same rate as private wealth (and productive capacity), meaning that the deficit must grow over time. The optimal level of the national debt (and growth of it) would thus depend on portfolio preferences of the public. If preferences for safe assets were to fall as the economy grows, then the optimal size (and growth) of the deficit would decrease. He concluded that the best combination of fiscal and monetary policy is a secular deficit with a low interest rate. (Adelman and Minsky [1960?])

He later continued in a similar vein in 1963 when he argued that an expansion led by growth of government spending would generate less fragility than one led by private 
spending. (Minsky 1963) This is because he recognized the interrelations among the three sectors (government, domestic private, and foreign - very similar to the approach taken by Wynne Godley) so that a private sector led expansion will worsen private balance sheets while moving foreign and government balances toward surpluses (more on these relations below). Later Minsky added the famous Kalecki profits equation to his arsenal—explicitly recognizing that budget deficits add to profit flows. As he emphasized in his 1986 book, "big government” has three effects: the Keynesian "multiplier”, the portfolio effects he had discussed in the early 1960s, and the profit income (Kaleckian) effects. (Minsky 1986c) Together these allow for powerful countercyclical impacts so long as the government is big and its budget is designed to move in a countercyclical manner.

After the Reagan tax cuts and increased defense spending, Minsky began to worry that the budget had become too slack, biased toward large deficits even as the economy neared full employment. He still argued for a big government: “A government whose spending is at least 16 percent and perhaps as high as 20 percent of prosperity GNP is necessary to protect the economy against a catastrophic decline in investment and profits." (Minsky 1986c) While the Reagan-era tax system "was not out of line”, the "expenditure system was too big by almost $\$ 100$ billion for a balanced budget if an approximation to full employment could be achieved.” (Minsky 1986c) He still recognized that occasional and even chronic budget deficits could be acceptable, but he insisted that even government must have a budget that could generate "a positive cash flow in circumstances that it is reasonable to expect will occur...A government can run a deficit without suffering a deterioration of its creditworthiness if there is a tax and spending regime in place that would yield a favorable cash flow (a surplus) under reasonable and attainable circumstances.” (Minsky 1986c) For federal government debt to retain value, it-like any other debtor- " has to be able to generate a positive cash flow in its favor." (Minsky 1986c) Regarding the implication of the Reagan deficits, he concluded "there will either be a run from the dollar or a substantial debt repudiation through inflation. Either way, interest rates will rise to new highs as markets react and as the Federal Reserve either moves to protect the dollar or stop inflation.” (Minsky 1986c) 
Arguably, these events did not come to pass. There was no run from the dollar and no run-up of inflation. However, what is perhaps more important is that these 1986 statements by Minsky are not easy to square with his early 1960s beliefs. What is even more surprising is that between the 1960s and the 1980s, the U.S. had abandoned gold and the Bretton Woods system. If anything —and for reasons to be explored—the movement to a floating exchange rate (even if it is "dirty") should have relaxed, not tightened, fiscal restraints. As mentioned above, Minsky was aware of Abba Lerner's "functional finance" approach to deficits. He was also familiar with Knapp’s "state money" approach at least by the early 1980s (when he presented the ideas in his classes); his 1986 book included the statement that "the fact that taxes need to be paid gives value to the money of the economy.” (Minsky 1986c p. 231; Wray 1990, 1998, 2004) These 1986 statements appear to ensorse a much more traditional "sound finance" approach to government budgets—or, at least, what Eisner called a "deficit dove” position: cyclical deficits are acceptable, but persistent and secularly growing deficits are not. So the question is, did Minsky go wrong in his analysis of the Reagan budgets, and if so, where?

\section{FINANCING GOVERNMENT SPENDING (IN A FLOATING RATE REGIME)}

In the typical presentation, government faces a budget constraint according to which its spending must be "financed" by taxes, borrowing (bond sales), or "money creation." Since many countries prohibit direct "money creation" by the government's treasury, it is argued that "printing money" is possible only through complicity of the central bankwhich could buy the government's bonds while issuing bank reserves - effectively "printing money." (Lavoie 2003) Such a practice is nearly universally derided as bad policy that would almost certainly cause inflation, and, in fact, is illegal in some nations.

In reality, the government that issues the floating currency spends by issuing checks or by directly crediting bank accounts. Tax payments lead to debits of bank accounts. Deficit spending by government results in net credits to bank accounts. 
Usually, those receiving payments from government hold banking system liabilities while their banks hold reserves in the form of central bank liabilities. (We can ignore leakages from deposits—and reserves—into cash held by the non-bank public. These are always accommodated by the central bank - which provides reserves ("horizontally") to banks to meet the cash drain.) In short, government deficit spending takes the form of net credits to banks, which increases their reserves. (Wray 1998)

In the real world, things are a bit more complicated because it is common to separate treasury and central bank operations. In the U.S., the treasury writes checks on its central bank account, while reserves are credited to banks by the central bank. There are thus complex coordinating procedures adopted by the central bank and treasury. It is not necessary to pursue all of this accounting in more detail as it has already been examined in detail in Wray (1998), Bell (2000), and Bell and Wray (2002-3) for the case of the U.S. - and other countries adopt their own idiosyncratic procedures. The only logic that is necessary to grasp is that the government "spends" by emitting its own liability (mostly taking the form of a credit to banking system reserves), while a tax payment has the opposite effect: the government "taxes" by reducing its own liability (mostly taking the form of a debit to banking system reserves). All of this works only because the state has first exerted its sovereignty by imposing a tax liability on the private sector-which, ultimately, is the reason that the non-government sector will accept government liabilities as payment for the goods and services government buys.

As discussed, a government deficit means that some of the reserves created by spending are not drained by taxes. In systems like that of the U.S., in which reserves do not earn interest, profit seeking behavior of banks will lead to attempts to minimize net reserve holdings. When an individual bank holds more reserves than desired, it lends the excess in interbank markets-the fed funds market in the U.S. For this reason, aggregate excess reserves above what is legally required or desired will cause overnight rates to fall, while insufficient reserves cause overnight rates to rise-in either case, automatic (horizontal) central bank action is taken to offset this so that the central bank can hit its overnight rate. However, the central bank's ability to drain excess reserves is limited 
because it will run out of treasury debt to sell. Informal procedural rules can limit central bank purchases, although because the central bank buys assets by crediting banks with reserves, there is no theoretical limit to its ability to do this. In any case, there is a division of responsibilities such that the central bank is responsible for draining/adding reserves on a day-to-day basis, while the treasury drains/adds reserves over a longer run. It does this by selling/retiring sovereign debt.

Whenever it runs a sustained deficit, the treasury will be adding reserves to the system, which can generate excess reserves. Banks prefer interest-earning treasury debt over non-interest earning excess (undesired and/or nonrequired) reserves, hence there is no problem selling the treasury debt when deficits create excess reserves. Note, also, that if banks did not prefer to buy government bonds, the treasury (and central bank) would simply avoid selling them, and, indeed, would not need to sell the debt as the banks preferred to hold non-interest earning reserves. In other words, rather than deficits requiring the treasury to "borrow", logically, government deficits only require the central bank and treasury to drain excess reserves to avoid downward pressure on overnight interest rates. This means that the wide-spread fear that "markets" might decide not to buy treasury debt if budget deficits are deemed to be too large is erroneous: bonds are not sold to "borrow" but rather to drain excess reserves. If "markets" prefer excess reserves, then bonds need not be sold — and won't be because there will be no pressure on the overnight rate to be relieved.

Bond sales (or purchases) by the treasury and central bank are triggered by deviation of reserves from the position desired (or required) by the banking system, which causes the overnight rate to move away from target (if the target is above zero). Bond sales by either the central bank or the treasury are properly seen as part of monetary policy designed to allow the central bank to hit its target. This target is exogenously "administered" by the central bank ("horizontally" maintained by ensuring banks have the desired quantity of reserves). Obviously, the central bank sets its target as a result of its belief about the impact of this rate on a range of economic variables that are included 
in its policy objectives. In other words, setting of this rate "exogenously" does not imply that the central bank is oblivious to economic and political constraints it perceives.

In this discussion we have assumed that the nation is on a flexible exchange rate system. Of course, Minsky’s earlier writings were completed during the fixed exchange rate Bretton Woods era. Such a system necessarily constrains both fiscal and monetary policy. The central bank's target interest rate will be set with a view to stabilizing the exchange rate. This removes a "degree of freedom" because economic outcomes that might pressure the exchange rate can cause the central bank to change its target rate. For example, if it is believed that a budget deficit can raise demand and increase a trade deficit or cause inflation-either of which might negatively impact the foreign exchange value of the currency — the central bank might react by raising the target interest rate to increase rest of world (ROW) demand for the currency. Fiscal policy is also constrained by perceived pressures on exchange rates. To be sure, even nations on floating exchange rates formulate monetary and fiscal policy with some consideration given to possible impacts on exchange rates. However, with fixed exchange rate systems, there is very little room to maneuver: foreign currency and gold reserves are ultimately the only convincing weapons in the policy arsenal to maintain convertibility at a fixed exchange rate. To the extent that expansionary fiscal and monetary policy would threaten international reserves, they must be foregone. What we might call sovereign power is severely reduced. It is no coincidence that countries operating with fixed exchange rates today strive for policy austerity — and that they are quickly punished when they adopt overly expansionary policy. The principles discussed above do not really apply to government finance in a nation on a fixed exchange rate. Effectively, government liabilities are "backed by" foreign currency and gold reserves as there is a promise to convert domestic currency at a fixed exchange rate. Adoption of flexible exchange rates increases independence of domestic policy.

In conclusion, the notion of a "government budget constraint” only applies ex post, as a statement of an identity rather than as an economic constraint in today's floating rate system (except for those nations that adopt fixed exchange rates). Ex post, 
any increase of government spending is matched by an increase of taxes, high powered money (reserves and cash), and/or sovereign debt held. But this does not mean that taxes or bonds actually “finance” or “constrain” the government spending. Government can enact provisions that dictate relations between spending and tax revenues (a legislated balanced budget, for example); it can require that bonds are issued before deficit spending takes place; it can require that the treasury have deposits at the central bank before it issue checks; and so on. These provisions can constrain government's ability to spend at the desired level. However, such constraints are self-imposed — that is, discretionary, not economically necessary_although they may well be politically necessary.

While Minsky did not explicitly detail all of this, he certainly understood and emphasized balance sheet accounting, and had endorsed Lerner's functional finance approach that underlies the exposition above. Even in the early 1960s he had argued that there is no default risk on sovereign debt. If anything, that claim was made stronger by abandonment of Bretton Woods (as, previously, there was at least an implicit promise of convertibility at a fixed exchange rate-which would be broken if the currency were devalued). Still, by 1986 he was analyzing government as if it were a private agent that had to maintain the expectation that it could run surpluses. Where did Minsky go wrong?

A sovereign government does not need tax revenue in the same sense in which private economic units need income. This is because the government can impose a tax liability, which generates a demand for "that which is necessary to pay taxes" - the government's liability. It is certainly true that government needs taxes-because that is what creates the demand for HPM (high-powered money) in the first place. And if HPM is "too easy" to obtain, it can lose its value because no one needs to "work hard" to obtain it. It is not the prospect that government will be able to run a surplus under not implausible circumstances that gives money value, but rather the fact that the private sector must "work hard” to obtain it. If money "grew on trees”, its value would be determined by the effort required to harvest it. Minsky did argue somewhat along these 
grounds asserting that providing welfare tends to be inflationary, while providing jobs is not.

This might not be too much more than a quibble over imprecise language. Minsky emphasized that a robust economy should generate a budget surplus, and it is the expectation that government can run a surplus that allows money to retain value. A robust economy would result from falling desire of the private sector to accumulate net saving in the form of government liabilities (HPM plus bonds) — so that it is spending more than its income (see below). If the budget did not move to surplus, allowing liabilities to reflux to government (for "retirement”), the supply would be too great to be consistent with stable value. Hence, the "automatic stabilizer" feature of the federal budget helps to ensure that the budget deficit is at the right level to supply the right amount of government liabilities consistent with the private sector's desire to net accumulate them. If Minsky had simply stated that the Reagan budget did not have sufficient automatic stabilization on the

upswing to attenuate a boom, he would have been on strong theoretical grounds - even if empirically it appears that he was mistaken. (The Reagan deficits did decline with expansion, and the Clinton boom generated a uniquely large budget surplus-indicating that there was a strong counter-cyclical bias built into the budget.)

\section{THE CURRENT FISCAL BALANCE}

Following Godley, we can think of the economy as being composed of 3 sectors: a domestic private sector, a government sector, and a foreign sector. (Godley 2005) If one of these spends more than its income, at least one of the others must spend less than its income because for the economy as a whole, total spending must equal total receipts or income. So while there is no reason why any one sector has to run a balanced budget, the system as a whole must. In practice, the private sector traditionally runs a surplusspending less than its income. This is how it accumulates net financial wealth. For the U.S. this has averaged about 2-3\% of GDP, but it does vary considerably over the cycle. (See Figure 1.) Private sector saving (or surplus) is a leakage that must be matched by an injection. Before Reagan the U.S. essentially had a balanced foreign sector; the current account swung between small deficits and surpluses. After Reagan, the U.S. ran growing 
trade deficits, so that today the current account runs nearly 6\% of GDP. That is another leakage that will be explored in more detail below.

In the U.S., the government sector taken as a whole almost always runs a budget deficit, reaching to around 5\% under Reagan and both Bushes. For the U.S., that is the injection that offsets the "normal” private and foreign sector leakages. With a traditional private sector surpl. of 2-3\% and a more or less balanced trade account, the "normal” budget deficit needed to be about 2-3\% during the early Reagan years. This would be consistent with Minsky’s early 1960s insights that government ought to run a growing budget deficit. Until the Clinton expansion, the private sector never ran a deficit. However, since 1996 the private sector has been in deficit every year except one (during the depths of the recession), and that deficit climbed to more than 5\% of GDP at the peak of the boom. This actually drove the federal budget into surplus as high as $2.5 \%$ of GDP. With the trade deficit at about 4\% of GDP, the private sector deficit was the sum of the overall budget surplus and the current account deficit. While almost all economists and policy makers thought the Clinton budget surplus was a great achievement (and projected the surplus to continue for 15 years or more), they never realized that by identity it meant that the private sector had to spend more than its income on a hitherto unknown scale, so that rather than accumulating financial wealth it was running up debt. The surplus was short-lived, as it drove the economy into recession.

As mentioned, the trade deficit represents a leakage of demand from the U.S. economy to foreign production. There is nothing necessarily bad about this, so long as we have another source of demand for U.S. output, such as a federal budget that is biased to run an equal and offsetting deficit. Private sector net saving (that is, running a surplus) is also a leakage. As discussed above, that was typically 2-3\% in the past. If we add in the current account deficit that we have today (about 6\% of GDP), that gives us a total “normal” leakage out of aggregate demand of 8 or 9\% of GDP.

This leakage would have to be made up by an injection from the third sector, the government-the only way to sustain such a large leakage is for the overall government 
to run a deficit of that size. Since state and local governments are required by constitutions and markets to balance their budgets, and on average actually run surpluses, it is up to the federal government to run deficits. The federal budget deficit is largely nondiscretionary over a business cycle, and at least over the shorter run we can take the trade balance as also outside the scope of policy.

A driving force of the cycle, then, is the private sector leakages (however, this is not to be interpreted incorrectly as an endorsement of the view that leakages "cause" or “finance” injections — which has got it backwards). When the private sector has a strong desire to save, it tries to reduce its spending below its income. Domestic firms cut production, and imports might fall too. The economy cycles downward into a recession as demand falls and unemployment rises. Tax revenues fall and some kinds of social spending (such as unemployment compensation) rise. The budget deficit increases moreor-less automatically. This is what happened in 2000 when the private sector went to surplus and the budget turned around to deficit. Incredibly, the private sector's surplus was short-lived as it quickly resumed its deficit spending. Unlike the 1990s, however, only the household sector is now driving the private sector's deficit-the business sector has maintained a surplus since 2000. It now appears the private sector might be cooling off, and the Bush budget deficits are starting to rise again. Of course, we cannot predict when the private sector will finally return to a more "normal” surplus, nor can we predict how much the current account deficit will be affected by a slowdown. It is probable that the trade deficit will fall by several percent of GDP if America goes into a recession, which will reduce the necessary fiscal deficit commensurately. Still, it is not at all impossible that the budget deficit will rise above 6\% of GDP if the private sector moves into surplus.

The U.S. experienced something highly unusual during the Clinton expansion and since because the private sector has been willing to spend far more than its income; the normal private sector leakages turned into very large and persistent injections. The economy grew quickly and tax revenues literally exploded. State governments and the federal government experienced record surpluses. These surpluses represented a leakage 
that brought the expansion to a relatively sudden halt. Bush's tax cuts plus spending on the "war” against terrorism have reduced and perhaps removed the Clinton-era bias toward surpluses at moderate rates of growth. However, the budget still seems to be sufficiently tight — given the large trade deficits — that the "normal" private sector balance now must be a large deficit in order for the economy to grow robustly.

Rather than the government sector being the main source of injections that allow the leakages that represent private sector savings, we now have the private sector dissaving in order to allow the foreign leakages. This sets up a highly unstable situation because private debt ratios rise quickly and a greater percentage of income goes to service those debts. While Fed policy normally doesn't matter much, in a highly indebted economy, rising interest rates can increase debt problems very quickly — setting off bankruptcies that can snowball into a 1930s-style debt deflation. The current situation seems to drive home Minsky’s 1960s view that the budget must normally be in deficit, and that the deficit must rise in absolute terms over time. A balanced budget or surplus will be achieved only in run-away expansions, unless the U.S. trade account takes an unexpected and very large turn in favor of U.S. exports. Later we will return to the sustainability of the current private sector stance, and by implication to the sustainability of the fiscal and foreign sector stances. First, let us turn to Minsky's views on the external balance.

\section{MINSKY’S VIEWS ON THE EXTERNAL BALANCE}

Since the Reagan years, the U.S. trade deficit has grown steadily to a record $6+\%$ of GDP. As discussed, this has negative consequences for U.S. aggregate demand, and also for domestic profits as demonstrated in the Kalecki equation. In the current situation, the external (current account) deficit of about 6\% of GDP equals the sum of the private sector deficit of $2 \%$ of GDP and the government budget deficit of $4 \%$ of GDP. (See Figure 2.) Here we look at the implication of a continuing and growing trade deficit for national income flows and external indebtedness to assess possible national fragility. The question is whether it makes sense to apply Minsky’s classifications to the U.S. as a whole: is the U.S. a speculative or Ponzi finance unit? 
In several pieces, Minsky used the "four tiers" perspective on balance of payments. (Minsky 1979, 1986a) The four tiers are: “(1) current imports and exports of goods and services, including remittances and other invisibles; (2) receipts and expenditures due to income from capital assets owned abroad; (3) long-term private investments; and (4) short-term debts or the movements of international reserves (gold) among countries.” (Minsky 1979 p. 111; see also 1986a p. 9) There is also a fifth tier (military expenditures and government investment abroad), although of lesser importance. In the 1960s the U.S. had an overall balance of payments deficit, but the first two tiers were positive. U.S. private investments abroad (tier 3) offset the surplus on the first two tiers, allowing the ROW to accumulate small net positions in short-term dollar assets. This, according to Minsky, was consistent with the dollar serving as the international reserve currency. While the dollar was kept "scarce", the small balance of payments deficits ensured a steady supply of dollars needed by the ROW for use as international reserves. However, after 1971, tier 1 turned increasingly negative, and by 1977 it exceeded the tier 2 surplus by a significant amount. Minsky (1979) argued that so many short-term dollar assets were being accumulated by the rest of the world that the dollar's status as the international reserve currency was threatened. He argued that for the dollar to retain this position, the tier 1 deficit would have to be reduced so that it would be near the tier 2 surplus. In that case, U.S. foreign investment—representing net accumulation of long-term assets-would be approximately equal to accumulation of ROW holdings of short-term dollar assets.

Minsky (1979) doubted that depreciation of the dollar could achieve such a balance, for several reasons. First, he insisted that in international trade, price is a device for determining where profits will be realized. In other words, given that production of internationally traded goods and services can and does take place through a number of stages that can be allocated among a number of locations, what is recorded as imports and exports largely consists of movement of products and services within multinationals. The pricing of these activities is undertaken at least partially on consideration of the most favorable geographic location and stage of production to record profits. Changing the 
value of a currency would not alter that decision in a predictable way. Second, depreciation could shake confidence in the dollar, and generate inflation in the U.S. that would further erode confidence. This could generate a run on the dollar that could lead to financial crises, a crash, and a world-wide recession.

Finally, Minsky argued that smooth adjustment of trade imbalances to currency depreciation would work only in a world in which finance does not matter. In the real world, depreciation of the international reserve currency would have far-reaching financial impacts. For example, dollar depreciation would reduce home currency values of exports of other nations, even as it favored U.S. exports. The effect on debtor ability to meet financial commitments could have multifarious and unpredictable impacts. The international financial system needs a strong "banker", and if the U.S. is to fulfill that role, the dollar's value must be maintained.

This emphasis on the rest of the world's necessity of meeting dollar-denominated liabilities was stressed in the aftermath of the LDC (less-developed country) debt crisis set off by Reaganomics and its high interest rate policies. Minsky (1986a) discussed the vast international network of dollar denominated debt that committed developing nations to large cash payments to U.S. and non-U.S. creditors. He analyzed the U.S. as a bank, and the ROW as depositors and borrowers. Typically the wealthier nations in the ROW (and OPEC nations) were the depositors, while the poorer developing nations were debtors. The dollar had to be made available on a large scale so that debtor nations could service debts. This constrains U.S. policy because high interest rates (that might be used to temper excessive U.S. demand) would reduce ability of debtor nations to service their debt. Alternatively, overly expansionary U.S. policy might lead to undesirable exchange rate effects. Further, Fed policy is constrained because the Fed has become responsible for lender of last resort intervention to the whole international financial system. Its role as banker to the world places limits on independence of domestic policy.

The explosion of third world dollar debt after the run-up of oil prices in 1979 had led to the creation of huge interest and principle payment flows denominated in dollars. 
These nations had to earn dollars from tier 1 to service tier 2 payments-if not they could quickly become Ponzi finance units. Any significant exchange rate movements would have large impacts on the world's financial system. Further, Minsky now recognized the overriding importance of U.S. trade deficits in generating the dollars needed by the ROW to service their debts. At the same time, he saw the impacts on U.S. employment (especially in manufacturing), that would generate pressure for protectionist policy. That, however, would only generate worldwide financial crisis. (1986a)

Of course, the U.S. trade deficit did continue to grow over the course of the 1980s. Minsky proposed several alternatives to dollar depreciation to rectify imbalances. Among the more conventional policies he advocated were tariffs on imports, excise taxes, and direct controls. His most unconventional proposal was that the U.S. treasury should issue long term bonds denominated in foreign currency to reduce the supply of short-term dollar debt. He claimed this would reduce the threat of a run on the dollar. (Minsky 1979; [1978?]; see critique below) Because of the impact of a trade deficit on aggregate demand, employment, and aggregate profits, Minsky also argued for a chronic budget deficit. At the same time, he called on other "rich nations" to grow, abandoning modern mercantilist policy that relies on trade-led growth. Importantly, Minsky argued that a "cross of debt” had replaced William Jennings Bryan's “cross of gold” as the major impediment to world-wide economic growth. The problem was that if the U.S. were the only engine of growth, this might have undesirable consequences for the dollar, and thus for the international financial system.

It was at this time that Minsky applied his hedge, speculative, and Ponzi classification to countries. Countries with dollar-denominated debt need to run a surplus on their balance of trade (termed tier 1 above) sufficient to service their payments on outstanding financial liabilities (tier 2). This would allow them to roll-over liabilities, maintaining a speculative position. If these tier 1 earnings were insufficient, then the country would be in a Ponzi situation. Creditor nations, however, were obliged to run balance of trade deficits, supplying the dollars needed by debtor nations. With the U.S. operating as the world's banker, it would have to run a continuous tier 1, trade, deficit. 
Still, the U.S. would have to force a cash flow to itself, through one of the other tiers. A ROW preference for dollar deposits and other short term assets (tier 4) would keep the dollar strong, but this could require high interest rates and believable anti-inflation policy. Net investment in the U.S. (tier 3) could also force a dollar reflux. Finally, net flows on tier 2 (net income receipts from U.S. holdings of foreign assets) could also keep the dollar strong in the face of a U.S. trade deficit. In the next section we examine the US's current position to determine whether the classifications can be applied to the nation.

\section{THE U.S. BALANCE OF PAYMENTS DEFICIT TODAY}

Of course, today's U.S. trade deficit is much larger relative to GDP than it was when Minsky was writing. Further, the US has since become the world's biggest debtor nation. At the end of 2004, the US net foreign asset position stood at negative $\$ 2.5$ trillion (assets were about \$10 trillion while liabilities totaled about \$12.5 trillion). (Gourinchas and Rey 2005) Almost all the liabilities were denominated in dollars, but some $70 \%$ of assets were denominated in foreign currencies. In 1952 the U.S. had been a large net creditor nation, with net assets equal to about 15\% of GDP; that was slowly eroded over the years and finally turned negative around 1988, after which the negative net position grew rapidly to about 26\% of GDP by the end of 2004.

However, in spite of the large and growing negative asset position, the U.S. still enjoys a positive net income flow on assets (Minsky’s tier 2). This is because the total average rate of return on assets held by the U.S. exceeds the total average rate of returns paid by the U.S. on its liabilities by about 332 basis points. (Gourinchas and Rey 2005) This excess return was decomposed by Gourinchas and Rey into a return effect (higher returns for assets of the same risk class) and composition effect (higher returns due to riskier asset classes). They attribute 245 basis points of the excess return to the return effect; while there are composition effects they are much less important. What this means is that for similar risk classes, the U.S. pays a far lower return than it receives on foreign assets. 
Interestingly, the excess return has increased sharply since the break-down of Bretton Woods, supporting the argument that the rest of the world views U.S. dollar assets as safer than domestic assets of the same risk class (and perhaps indicating that relative safety increased once the U.S. abandoned Bretton Woods and gold). This is also borne out by the finding that larger excess returns exist for relatively liquid equity and debt, but almost no excess return was found for direct foreign investment. (Gourinchas and Rey 2005) Finally, Gourinchas and Rey provide an estimate of the "tipping point" at which U.S. net indebtedness will lead to negative net income flows, given the 332 excess basis point return: when U.S. external liabilities reach 1.43 times external assets held (the ratio currently stands at 1.34). However, the tipping point will depend on the movements of the excess rate of return-if it were to rise, net liabilities could continue to rise without reversing net income flow.

Note also that exchange rate movements have a very large impact on the dollar valuation of U.S. assets (depreciation of the dollar raises foreign asset values) but almost no effect on U.S. liabilities (since almost all are denominated in dollars). Hence the ratio of liabilities to assets can change significantly with the value of the dollar. Gourinchas and Rey calculate that a ten percent devaluation of the dollar generates a net capital gain to the U.S. equal to $5.9 \%$ of US GDP. Thus, rising excess returns plus depreciation of the dollar can allow the U.S. to maintain positive net income flows even in the face of growing net international indebtedness. However, the authors characterize the current international position of the U.S. as "venture capitalist", with short-term liquid liabilities and long-term riskier assets, in contrast to its position in the 1960s when it was characterized by Minsky, Kindleberger and others as "the world's banker" because of its maturity mismatch (short-term liabilities and longer-term assets). Further, there is a currency mismatch with today's floating rates, since U.S. debts are in dollars but the majority of external assets are in other currencies. Finally, while the U.S. currently enjoys positive net income in spite of its net indebtedness, this could turn around-indeed, some might argue that it inevitably will. 
All of this seems to indicate that the U.S. is in an increasingly precarious situation. The question is whether the U.S. nation can be called a speculative or Ponzi unit, on Minsky’s definitions. Recall from above that Minsky had used these terms to identify highly indebted developing nations. However, these are users of the dollar: their external debts are mostly in dollars, and their governments (treasury and central bank) cannot issue the dollar. While their banks can offer dollar deposits and make loans denominated in dollars, they do not have direct access to the Fed. Further, questions of debt problems or potential insolvency can cause a run on their currency, which depreciates relative to the dollar. This can cause domestic inflation and increase the dollar debt service burden. As the issuer of the dollar, the U.S. is in a quite different position. Before we examine the bigger question of the application of the classifications to the U.S., let us first examine how the U.S. becomes indebted, distinguishing between external government debt and external private debt.

As discussed, the U.S. federal government incurs a deficit when its spending exceeds tax revenue. To summarize the argument above, modern governments with floating exchange rates and sovereign currencies spend by cutting checks (or directly crediting bank accounts); this leads to a reserve credit to the banking system. A federal government tax receipt leads to a reserve debit, so when expenditures exceed taxes over any period (say, a year), this results in net credits. If this results in excess reserves for the banking system, government debt is sold (by the Treasury in the new issues market, and/or by the Fed in the overnight market) to drain the excess. If it did not drain excess reserves, the overnight interest rate would be driven below the Fed's target rate. The implication of this is two-fold. First, sovereign government can always service its debt by crediting bank accounts (which is the way it accomplishes any kind of spending). Second, government issues debt to drain excess reserves, not to "borrow" in the usual sense of the term. And, the purpose of this is to hit the interest rate target set by monetary policy. If the debt were not sold, banks would hold excess reserves and the overnight interest rate would be driven toward zero (or toward the support rate in countries that pay interest on reserves). It does not matter where the ultimate holder of U.S. government debt resides- 
sale of bonds drains banking system reserves, and the purpose is to hit the monetary policy rate target.

Some economists worry about what would happen if the government tried to sell bonds ("borrow" in their terminology) but there were no foreign demand for them (no foreigners wanted to "lend" in their terminology). The answer is that if government bonds are offered but find no buyers, then the banking system must not hold excess reservesthus, there is no reason to sell bonds. This does not mean that a government deficit can never be too big-inflationary - but it does mean that deficits do not imply a necessity to “borrow.” U.S. budget deficits allow the nongovernment sector (including foreigners) to accumulate claims on the U.S. government. These claims will be in some combination of high powered money (reserves and cash--HPM) and interest-earning bills and bonds, determined in a fairly straightforward manner by private preferences for HPM versus bills and bonds, plus government commitment to maintaining positive overnight interest rates (as well as possibly trying to influence the term structure of interest rates). There is no reason to fear that Chinese will stop "lending” to the US treasury-if China did not buy bonds, then HPM would be accumulated.

Let us turn to private sector external debt. When a U.S. non-sovereign consumer purchases an imported Toyota, she either gives up income or sells an asset or issues a liability to finance the purchase. The Japanese exporter holds a dollar claim on a US bank that probably will be converted to a yen claim on a Japanese bank, which in turn will convert a dollar reserve to a yen reserve at the Bank of Japan (although total yen reserves at the Bank of Japan (BOJ) will rise only if required/desired reserves rise-otherwise, the BOJ “sterilizes” or “accommodates” by an offsetting action). Alternatively, the Japanese bank could keep dollar reserves, or could convert them to U.S. Treasury debt-which is essentially just interest-earning reserves. When all is said and done, the American holds a new auto, and she used her income, or sold an asset, or committed herself to payments on debt. As economists are fond of saying, there is no free lunch for the individual consumer-and a trade deficit can be associated with rising indebtedness of consumers. However, increased American purchases of domestically produced output have exactly 
the same result, as they are financed in exactly the same way: consumer debt can rise. And just as in the case of domestically-held debt, the consumer might default.

By contrast, if the U.S. government chooses to import a Toyota, it truly can "get something for nothing”-issuing dollar reserves that eventually find their way to the Bank of Japan. Is this due to "dollar hegemony"? Not really. Any sovereign State obtains "something for nothing" by imposing a tax liability and then issuing the currency used by those with tax liabilities to meet the obligation. The only difference here is that the U.S. government has obtained output produced outside the U.S., by those who are not subject to its sovereign power-in other words, by those not subject to U.S. taxes. However, even within any nation there can be individuals who avoid and evade taxes imposed by the sovereign power, but who are still willing to offer their output to obtain the sovereign's currency. Why? Because those who are not able to avoid and evade taxes need the currency, hence, are willing to offer their own output to obtain the currency. The U.S. dollar has value outside the U.S. because U.S. taxpayers need the currency. By this I do not mean to imply that U.S. currency is only used to pay taxes, or that those who hold U.S. currency or reserve deposits at the Fed do so on the knowledge that U.S. taxpayers want high powered money to pay taxes. Analytically, however, it is the taxing power of the U.S. government that allows it to issue currency and reserves that are demanded domestically and abroad.

Much of the external U.S. dollar liabilities are government bonds. A U.S. trade deficit allows external accumulation of reserves in foreign banks or foreign branches of U.S. banks. Any excess reserves are offered in the overnight and Eurodollar markets, lowering interest rates. As the fed funds rate begins to fall below the Fed's target, bond sales are triggered—by the Fed — that together with new issues by the Treasury soak up the excess reserves. At the same time, the U.S. budget deficit provides a continuing flow of reserves both domestically and, through the vehicle of the U.S. current account deficit, externally. It is this budget deficit which, ultimately, is responsible for the excess reserves that pressure overnight rates. The current U.S. private sector deficit plus government deficit together comprise the "twin" to the foreign sector deficit, with the budget deficit 
creating the HPM plus interest-paying debt the nongovernment sector wants to accumulate-both domestically and externally. 


\section{CONCLUSIONS}

It is perfectly reasonable to apply Minsky's classifications to indebted units in the private sector, although there is little reason to distinguish between domestic and foreign creditors when doing so. As we know, the U.S. private sector taken as a whole has been spending more than its income on a very large scale, with almost no let-up since 1997. This has accelerated the growth of private sector debt relative to income. (See Figure 3.) Over this period, it is likely that many individual units have moved from hedge to speculative positions, and even to Ponzi positions. However, the aggregate data relating total debt to personal disposable income really sheds little light on this. If every private unit (individual firms and households) had the same ratio as the aggregate ratioapproximately $150 \%$--it is conceivable that all could service their debt at current (and still relatively low) interest rates. (For example, at an average interest rate of 6\%, debt service on current private sector debt would equal 9\% of personal disposable income-6\% of $150 \%=9 \%$--a not intolerable burden.) Indeed, while debt service ratios have risen, the rise is not that dramatic. In the past few years, the business sector's income growth has been more rapid than growth of debt. Households have been in the opposite situation, but it is not likely that many are in truly speculative positions. Rather, the greater danger is simply that they will cut back other types of spending in order to service debt (and higher energy costs)—which could lead to recession.

It is likely that Minsky could make a quite strong case that the U.S. economy's fragility has increased since the late 1990s, given fairly slow growth of income and employment and more rapid growth of debt. Creditors holding the debt of U.S. households and firms face the prospects that some individual debtors will not be able to service their debts. It is conceivable that foreign creditors face more risk than do domestic creditors (although the current interest rate differential does not reflect that). For example, the Fed and Congress might be less willing to step in to preserve asset values for external creditors. It is also possible that exchange rate movements could more significantly affect foreign creditors, if their claims are on debtors that would be hurt by dollar devaluation, for example. However, in spite of such possible differences of 
interests and impacts, it does not seem necessary to create a special classification system to be applied to the portion of U.S. private sector debts held by foreigners. Nor, for the reasons discussed, does it seem appropriate to label a whole nation a "speculator" or "Ponzi" economy merely because some of the debt is held externally. To repeat: the U.S. private sector is probably more financially fragile that it was a decade ago, and many units are speculative and Ponzi, but that would be just as true even if all debt were held domestically. Indeed, it is possible that the U.S. economy would be more fragile if all the debt were internally held-since cascading defaults would wipe out domestic wealth. When U.S. debtors default on external debt, foreigners bear the direct burden-although secondary affects would come back to the U.S., for example, if that led to a world-wide financial crisis.

This is not to deny that continued (and perhaps growing) U.S. trade deficits might lead to dollar devaluation. Given that U.S. debts are almost all denominated in dollars, devaluation would not be likely to have large direct consequences on ability of U.S. households and firms to service debt. (And, as noted above, devaluation leads to capital gains in the U.S.) Assuming — as is likely — that devaluation has little impact on U.S. imports, to the extent that import prices rise there could be some financial pressure on U.S. debtor households and firms. There could be other knock-on effects of a devaluation, but these are not likely to be so significant that we would have to revise our analysis. While individual households and firms might have to default on debt, and while this could generate additional pressures on the dollar, the central bank and treasury would be able to step-in to prevent any snowballing debt deflation process.

On the other hand, if the U.S. debts were denominated in other currencies (say, if the U.S. were a Mexico), the effects of a devaluation on U.S. fragility would be very much larger. The dollar income of US resident households and firms could not be used directly to service the foreign currency debt. This is where we would return to Minsky's four tier analysis. The relevant variables would not be the total debt to disposable income ratio, or even total debt service ratios. Rather, earnings from net exports, net flows of foreign direct investment, net income flows from assets, and net accumulation of short- 
term assets would be the factors determining flows of foreign currencies to the U.S., hence, pressures on the dollar. The cost to households and firms of servicing foreign currency debts in this case rises directly as the dollar depreciates-as they give up more of their dollar income to obtain foreign currency (or go into debt to borrow dollars). Depreciation could in that case push them into speculative or Ponzi positions.

While I think it is still a bit misleading to apply Minsky’s classifications to the nation that issues foreign currency liabilities merely because, for example, its tier one plus tier two net flows are negative and some households and firms are defaulting, it is easy to see why it is tempting to do so. Defaults could generate further devaluation, leading to more defaults. The ability of the central bank and treasury to intervene would be limited given that their holdings of foreign currency are limited. Some nations faced with such a situation "nationalize" the foreign currency denominated private debt as an alternative to watching their firms (and households) default. However, unlike the case of domestic currency debt, converting private foreign currency debt to government debt cannot eliminate default risk. Ultimately, this policy will fail unless the government can increase the flow of dollars (using one or more of the tiers), or can rely on official international institutions. For this reason, the usual Minsky classifications can be helpful in analyzing cases in which countries have external debts denominated in foreign currency such as the highly indebted developing nations that Minsky analyzed. At the same time, his proposal that the U.S. Treasury should issue foreign currency debt seems to be a particularly bad idea, that would put the U.S. toward a Mexico-type position.

Turning to the real world U.S. federal government, which is the source for a huge portion of the dollar assets accumulated by foreigners, it is easy to dismiss the claim that its financial position could become speculative or Ponzi. The federal government services its debt by crediting bank accounts. It does not face the same constraints faced by the private sector, indeed, it does not really have anything approaching an "income.” It is true that the government records tax revenue-it “accounts” for it — but it does not and cannot “spend” tax receipts. Whether it is spending to finance domestic purchases (of goods, services, or labor), to finance foreign purchases, or to pay interest on debt, it spends by 
crediting dollars to bank accounts. There is no limit to its ability to do so. If its actions set off a devaluation, it can still service its dollar debts. Whether we speak of the U.S. federal government's domestically-held or foreign-held debt, it is not appropriate to apply Minsky's classification system. Note that the government would be in a much different position if its debt were in foreign currencies, or if it promised to exchange its dollar liabilities for foreign currencies (or gold) at a fixed exchange rate. In those situations, it could be forced to default on its commitments.

Given today's current account realities, Minsky's call for a budget that can balance at high employment must be modified. To allow the private sector to strengthen its balances, the budget should be biased to run deficits somewhat larger than the trade deficit at full employment. This would move us toward a synthesis of his early 1960s writings on the fiscal balance and his later writings on the U.S. as "world's banker." With a chronic and growing current account deficit, the domestic private sector cannot achieve a surplus without a very large fiscal deficit. Continued private sector deficits increase financial fragility and would—it seems—lead to an eventual "Minsky crisis." Even if crisis is not on the horizon, returning private balances to a historically more normal surplus would mean a huge reduction of aggregate demand that is not likely to be fully compensated by a turn-around of the current account deficit. Only a large increase of federal deficits could allow the private sector to return to a "normal" surplus position.

It is likely that the trade imbalance is "unsustainable"—but not for the reasons usually cited (U.S. solvency). Rather, as U.S. consumers continue to run-up deficits and accumulate debt, they will probably eventually cut back spending. This will reduce imports, albeit by an unknown amount. Similarly, the U.S. budget deficit is also in some sense "unsustainable", but again not for the usual reasons. The budget deficit will rise if the U.S. private sector reduces its net spending; it will fall if the pace of private spending increases. U.S. spending by households and firms, in turn, may well depend on solvency questions. However, it is misguided to speak of the U.S. federal government, or the nation as a whole, facing financial constraints in a regime of sovereign currency and floating exchange rates. 


\section{REFERENCES}

Adelman, Irma and Hyman Minsky. circa 1960. "On the national debt and economic growth”, Manuscript in the Minsky Archives at The Levy Economics Institute.

Bell, Stephanie. 2000. Do taxes and bonds finance government spending? Journal of Economic Issues. 34:603-620.

- 2001. The role of the state and the hierarchy of money. Cambridge Journal of Economics, vol. 25, no 2, March, pp. 149-163.

and L. Randall Wray. "Fiscal Impacts on Reserves and the Independence of the Fed,” Journal of Post Keynesian Economics Winter 2002-2003, vol. 25, No 2, pp. 263-271.

Cornford, Andrew. 2005. "Basel II: The Revised Framework of June 2004.” Discussion Paper No. 178, United Nations Conference on Trade and Development, April.

Godley, Wynne. 2005. “Some Unpleasant American Arithmetic,” Policy Note 2005/5, The Levy Economics Institute of Bard College.

Godley, Wynne, Dimitri B. Papadimitriou, Claudio H. Dos Santos, and Gennaro Zezza. 2005. The United States and her Creditors: Can the Symbiosis Last? Strategic Analysis, The Levy Economics Institute of Bard College, September.

Gourinchas, Pierre-Olivier and Helene Rey. 2005. "From world banker to world venture capitalist: U.S. external adjustment and the exorbitant privilege,” NBER Working Paper Series, Working Paper 11563, August.

Lavoie, Marc. 2003. “A Primer on Endogenous Money.” in Modern Theories of Money: The nature and role of money in capitalist economies, edited by Louis-Philippe Rochon and Sergio Rossi, Cheltenham: Edward Elgar.

Minsky, Hyman P. 1986a."Conflict and interdependence in a multipolar world.” Studies in Banking and Finance, 4.

_ 1986b. "Stabilizing an Unstable Economy: The Lessons for Industry, Finance, and Government." Weltwirtschaft and Unterrelmerische Strategien, edited by Karl Aiginger, Vienna, Austria: Osterrichisches Institut fur Wirtschaftsforschung, pp. 31-44.

—. 1986c. Stabilizing an Unstable Economy. Yale University Press.

—. 1963. "Discussion.” American Economic Review, 53, pp. 401-412 
- 1973. "Devaluation, inflation and impoverishment: An interpretation of the current position of the American economy.” One Economist's View, Mark Twain Economic \& Financial Advisory Service, vol. 1, no. 1, November.

—. circa 1978. “The Dollar Crisis_An analysis and modest proposal,” Manuscript in the Minsky Archives at The Levy Economics Institute.

- 1979 "Financial Interrelations, the balance of payments, and the dollar crisis." Debt and the Less Developed Countries, edited by Jonathon David Aronson, Westview Press: Boulder, CO.

- circa 1986d. "Financial integration and national economic policy." Manuscript in the Minsky Archives at The Levy Economics Institute.

Prada, Paulo. 2006. "Brazil will buy back bonds issued during financial crisis,” The New York Times, 24 February.

Wray. L. Randall. 1998. Understanding Modern Money: The Key to Full Employment and Price Stability. Cheltenham, UK: Edward Elgar.

1990. Money and Credit in Capitalist Economies: The Endogenous Money Approach. Aldershot, UK: Edward Elgar.

- 2004. Editor, Credit and State Theories of Money: the contributions of A. Mitchell Innes, Cheltenham, Edward Elgar. 
Note on Figures: The following figures were developed at The Levy Economics Institute of Bard College, and are based on a model developed by Wynne Godley.

FIGURE 1: U.S. THREE FINANCIAL BALANCES

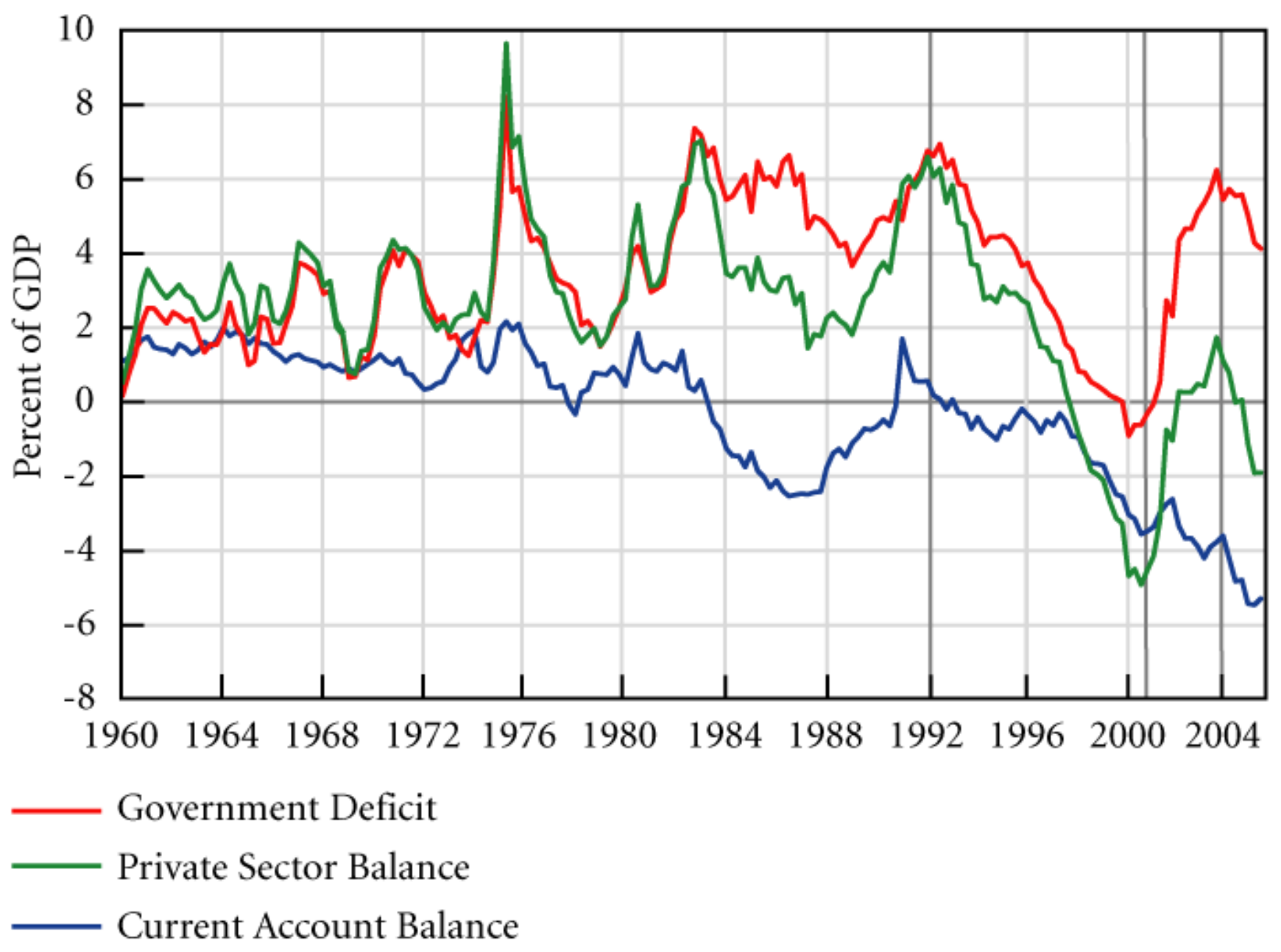

Sources: BEA and authors' calculations 
FIGURE 2: U.S. TRADE AND CURRENT ACCOUNT

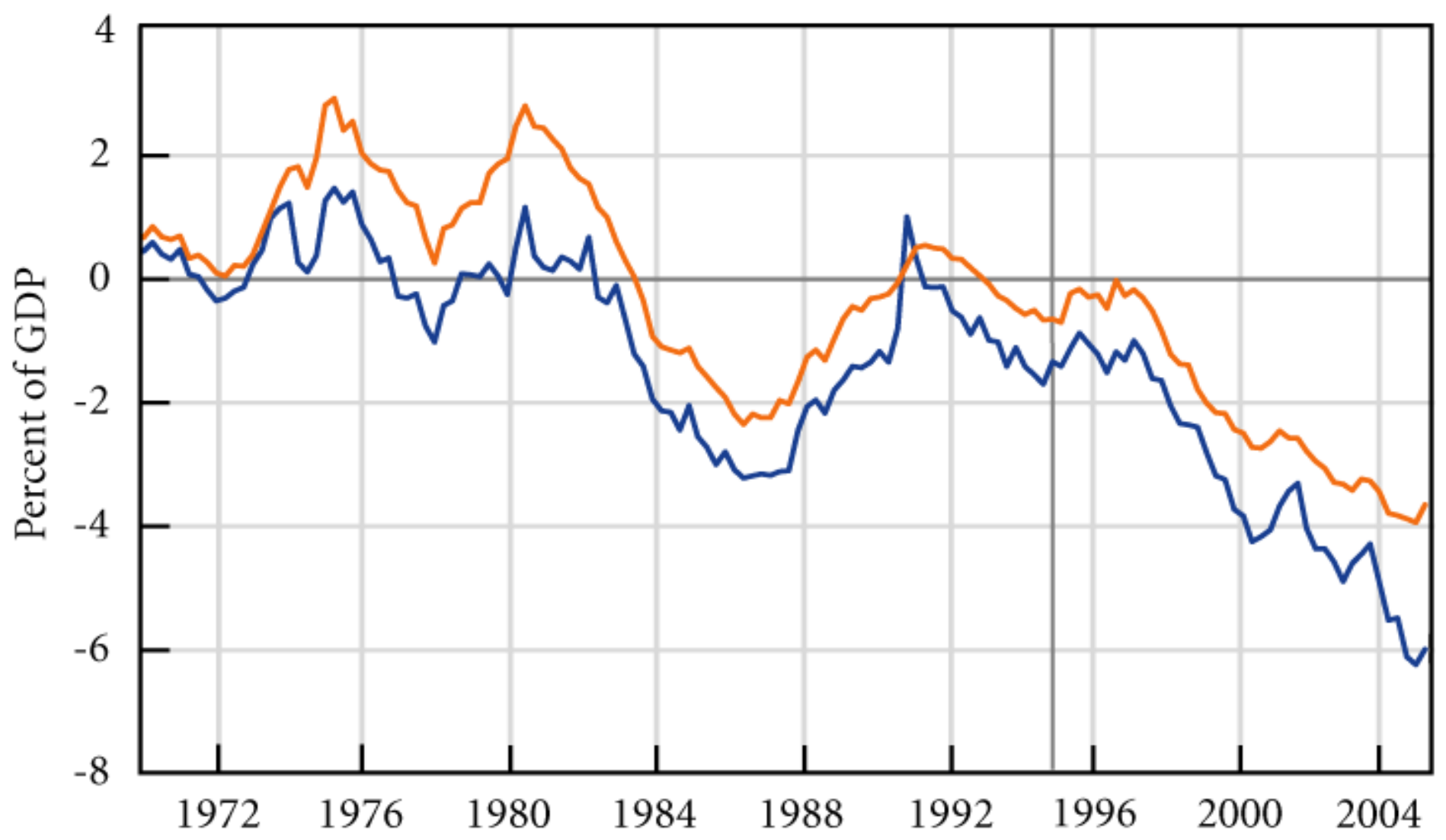

Trade Balance, Excluding Oil Imports

Current Account Balance

Sources: BEA and authors' calculations 
FIGURE 3: U.S. PRIVATE SECTOR DEBT

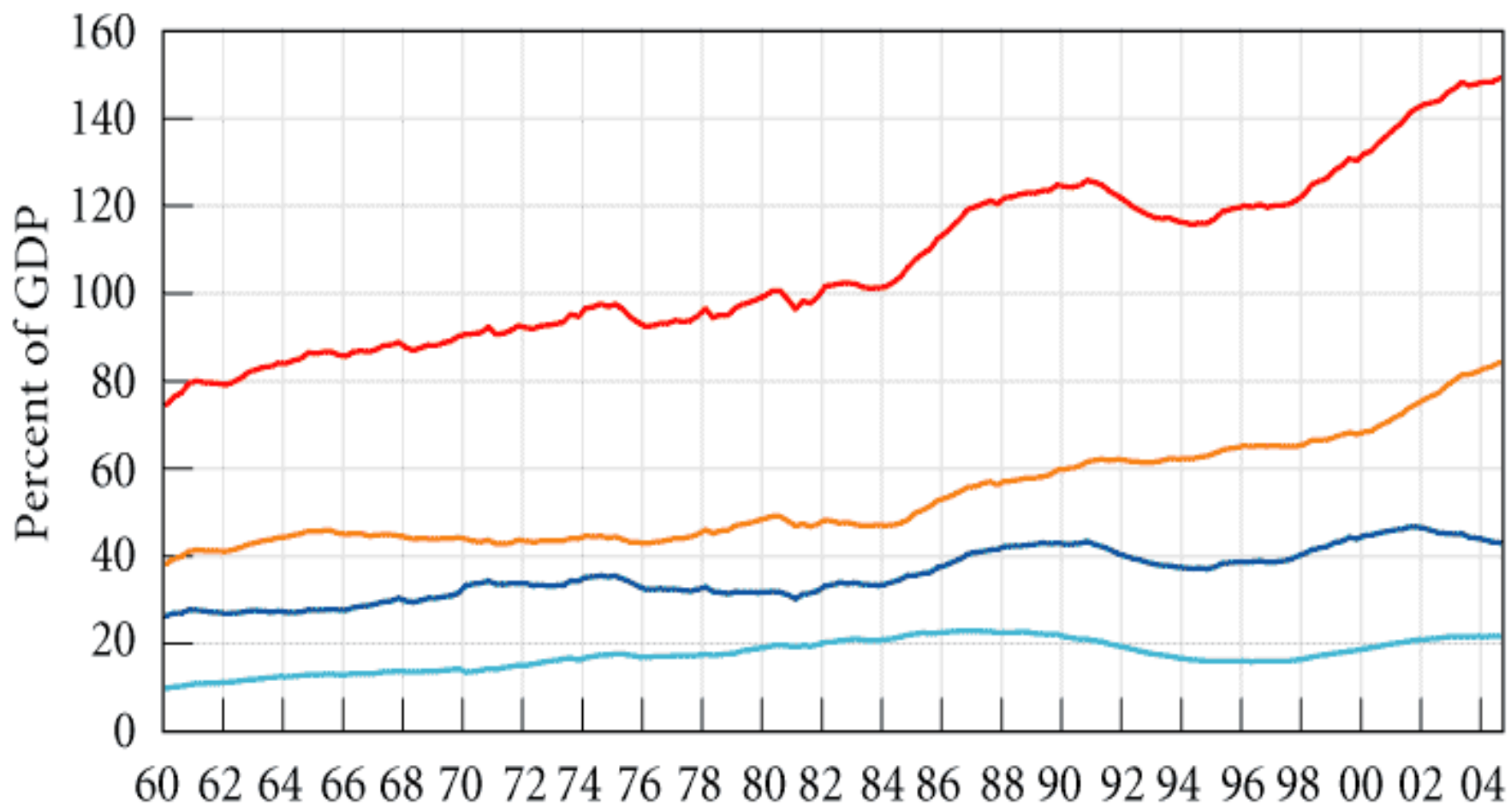

— Private Debt

— Household Debt

- Corporate Debt

- Noncorporate Business Debt

Sources: Flow of Funds and authors' calculations 